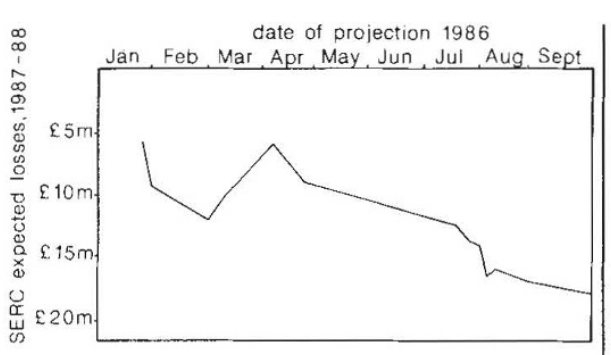

The UK Science and Engineering Council's increasing haemorrhage from its 1987-88 budget, with respect to plans put before the Treasury early in 1986, as the falling pound pushed up the cost of foreign-currency subscriptions to international programmes. Losses are now touching $£ 18$ million.

insists it will stick to the cash-limits it understands, in sterling, and refuses to insulate its payees from the consequences of their folly in making commitments in foreign currencies. Council sources perhaps unsurprisingly describe the argument for variable cash-limited budgets as "not getting very far". CERN, whose subscription is the council's largest, shows little sympathy; the issue is seen as Britain's self-inflicted wound, and one that Britain must sort out.

In October, the council will be considering to what extent any shortfall will have to be covered by cuts in studentships, or in research. If there are cuts, they will probably be at the margins of SERC's activity,

officials hint darkly. Training activities not directly connected with research such as the advanced course studentships, costing some $£ 10$ million or so annually may be threatened.

Moreover, there could be even more than $£ 18$ million to find because another international problem is looming for SERC: the extent to which the Treasury will wish to 'attribute' grants received by British researchers from the growing European Commission research programme. Under the strict interpretation of Treasury rules, the British science budget could be cut to keep a fixed level of science funding in Britain. At present little such 'attribution' appears to take place, but if European Commission research budgets increase dramatically next year (and 50 per cent is not unlikely), the Treasury seems likely to wake up to the possibilities and art.

This, however, would be seen as another self-inflicted wound. British scientists are highly successful at winning European funding, and certainly receive back more than the proportionate British subscription to the European Community. How much of the present European funding in Britain might be attributable to SERC? Dr Catterall considers it not in the council's interest even to "guesstimate". But the figure is likely to be in the region of millions of pounds. Robert Walgate

Solar power

\title{
Australia joins the solar race
}

Canberra

AN Australian team at the University of New South Wales, Sydney, reckons to be racing neck and neck with US laboratories towards the goal of an efficient silicon solar cell. But interest is now turning from the search for ever greater theoretical efficiency to the design of cells that will be economic in the field.

Australia has long been in the forefront of solar cell research, partly because of its latitude and its often cloudless skies but principally because of the remoteness of many of its communities. In the late 1970s, Australia was the largest market for solar cell applications.

Much of the recent running has been made by a group led by Dr Martin Green, itself part of the Microelectronics $\mathrm{Re}$ search Centre at the university, which has been singled out as one of ten centres of excellence by the federal government in Canberra. Last October, Green's group announced the design of a silicon cell with a conversion efficiency of just over 20 per cent, then the highest ever attained.

The essence of the Australian development is to etch $10 \mu \mathrm{m}$ microgrooves into the surface of a silicon wafer, which increases the efficiency of solar photon collection by internal reflection and reduces the chance of recombination between conduction electrons and electron holes by concentrating the formation of electronhole pairs near the $\mathrm{N}$-type silicon layer on the surface of the grooved structure. The grooves also increase the range-section area available for conduction by a factor of 3 , reducing the resistance of the cell.

Last year's record efficiency was obtained with a grooved cell coated with a thin layer of oxide, which appears to reduce lattice defects. Steps were also taken to reduce the distortion caused by the attachment of electrodes to the cell. Even so, the Australian record was eclipsed earlier this year, when a group at Stanford University in California announced the development of a cell with a conversion efficiency of 27.5 per cent, but only with the use of solar radiation concentrated on the active surface by a system of Suntracking Fresnel lenses.

Comparisons are difficult. Cells such as those developed at Stanford require steering systems, and can use only the direct component of solar radiation (on average, three-quarters of the total) while the costs are effectively determined by the Fresnel lenses. Green says that the two types of systems are at present roughly on a par. Concentrating solar cells are best

\section{Biology is the soft option in Albania}

Young Albanians are showing a distressing tendency to try to use higher education as a way of avoiding "productive labour", the youth daily Zeri $i$ Rinise complained recently. Instead of becoming "engineers, geologists and builders", they wish, the paper says, to become "lawyers, philosophers and biologists". The inclusion of biologists in the list is in marked contrast to other socialist countries, where biology is definitely production-orientated. (Do the scars of Lysenkoism linger yet, one wonders, in Stalinist Albania?)

This "petit bourgeois" mentality, the paper notes, is particularly reprehensible in that it affects workers and peasants, who want their children to find non-productive "intellectual jobs". It is understandable, Zeri $i$ Rinise notes sourly, if the children of doctors feel that they too should like to study medicine. But toilers in factory and field, it implies, should encourage their offspring to follow in their own, proletarian footsteps.

The issue is particularly important since Albanian university admission procedures are heavily weighted in favour of the children of workers and peasants - with the unspoken assumption that, in due course, they will return, with their new-won skills, to the ranks of the toilers. Nor is this weighting a merely symbolic one. According to the vice-rector of Tirana University, Hasan Mucostepa, this means that during the academic year 1985-86, some 50 per cent of all students at the university (Albania's principal higher educational institution) were the children of workers and peasants.

Vera Rich

suited for large-scale power production and excel in space, while direct solar panels of his own type are ideal in inaccessible places.

Green's team is now attempting to apply the lessons learned in the development of last year's cell to the world of mass production, where the high purity of the materials used will not be easily repeated. The work is supported by BP (British Petroleum) Solar Australia and the Sandia National Laboratories on behalf of the US Department of Energy.

Green reckons that his group is approaching a good compromise between cost and efficiency with a solar cell offering 18.8 per cent efficiency with a silicon wafer taken from BP Solar's production line. One important innovation has been the use of copper rather than silver contacts, which are embedded in slots cut by laser beams, well suited to mass production. It remains to be seen how best to scale up from the $2 \mathrm{~cm}$ square cells used last October to the $10 \mathrm{~cm}$ disks normally used.
Charles Morgan 